\title{
Haemolysins and extracellular enzymes of Listeria monocytogenes and L. ivanovii
}

\author{
R. BARCLAY*, D. R. THRELFALL and I. LEIGHTON†
}

Department of Plant Biology, The University of Hull, Hull HU6 7RX and TDepartment of Microbiology, Hull Royal Infirmary, Anlaby Road, Hull HU3 2JZ

\begin{abstract}
Summary. Of 120 laboratory-maintained strains of Listeria monocytogenes and two of L. ivanovii examined for haemolytic and lipolytic activity, 62 exhibited haemolytic activity alone, 20 of these showed haemolytic and lipolytic activity and 40 had neither activity. The $L$. ivanovii strains showed both activities. The results indicated a relationship between haemolysin production and lipolytic activity which was not explained by the serotype of the organism. In addition, the following hydrolytic activities were detected in the cell-free growth media of strains $L$. monocytogenes Boldy and $L$. ivanovii (formerly L. monocytogenes) Type 5 (substrates acted upon are given in parentheses): acid phosphatase (4-nitrophenylphosphate, naphthyl phosphate, glycerophosphate, phosphorylcholine and GTP); neutral phosphatase (4nitrophenylphosphate, naphthyl phosphate, phosphorycholine, NADP and UDPG); phosphodiesterase (bis-4-nitrophenylphosphate, ATP and NADP); NADase (NAD); phospholipase C (4-nitrophenylphosphoryl-choline, phosphatidyl choline and ethanolamine, and sphingomyelin); and lipase and esterase (triacetin, tributyrin, triolein, naphthyl-laurate, -myristate, -caprylate, -palmitate and -oleate, 4-nitrophenyl-acetate -laurate and Tween 80 ). The preparations also showed weak catalase activity. No evidence was found for the presence of RNAase, DNAase, peptidase/amidase, phosphoamidase, $\alpha$-amylase, glucosidase, galactosidase, pyranosidase or glucose aminidase.
\end{abstract}

\section{Introduction}

The clinical features of the diseases caused by Listeria spp. suggest that toxins and enzymes produced by the bacteria contribute to their pathogenicity. The toxicity is associated partly with the cell envelope (Stanley, 1949; Patocka and Mara, 1973) but much of it is associated with the extracellular products. The discovery that L. monocytogenes produces a thiol-activated haemolysin (Harvey and Faber, 1941) helped to explain the nature of the extracellular toxic activities of this organism. However, in early attempts to differentiate the toxic activities of the haemolysin from those of the cell envelope, cell-free culture filtrates rather than purified haemolysin were used. Later attempts to ascribe an enzyme activity to the haemolysin showed that the culture filtrates also contained lipolytic (Girard et al., 1963) and nicotin-

Received 10 May 1985; revised version submitted 20 Sep. 1985 and accepted 14 February 1989.

* Present address: Department of Microbiology, University of Reading, London Road, Reading RG1 5AQ. amide adenide dinucleotidase (NADase) activities (Siddique et al., 1974), although these were originally attributed to the haemolysin. The nature of the lipolytic activity has yet to be resolved because it has been attributed variously to the production of a lipase (Jenkins and Watson, 1971), phospholipase C (Leighton et al., 1975) and phospholipase C plus lipase (Khan et al., 1972). This report attempts to resolve the problems concerning the nature and production of the lipolytic activity and also to describe the presence of other, previously unreported, extracellular proteins that might contribute to the pathogenesis of listerial infections.

Previous reports (Girard et al., 1963; Khan et al., 1972) show that a soluble haemolysin is not produced by all strains of $L$. monocytogenes. Of 155 laboratory strains examined by Girard et al. (1963), nearly $30 \%$ failed to show haemolysis on horse, sheep, rabbit or human blood agar. Khan et al. (1972) confirmed that some L. monocytogenes strains did not produce haemolysin. In contrast, Seeliger (1961) could not verify reports of the complete loss of the haemolytic property in some strains and 
attributed the apparent loss of haemolytic activity to variations in the growth media. The differences in the reported lipolytic and haemolytic activities by $L$. monocytogenes may have been caused either by strain variation or by variation in the growth conditions. To determine whether there are differences between strains in these properties we examined 122 laboratory-maintained cultures for the production of haemolysin, esterase/lipase and phospholipase.

\section{Materials and methods}

\section{Organisms and media}

A collection of 120 laboratory maintained and freshly isolated cultures of $L$. monocytogenes and two strains of L. ivanovii (formerly L. monocytogenes) was obtained from the Department of Microbiology, Hull Royal Infirmary, Hull. Strains were maintained on tryptose agar. Media used for morphological and biochemical studies were: blood agar (defibrinated horse blood $5 \% \mathrm{v} / \mathrm{v}$ in Blood Agar Base No. 2, Lab M); egg yolk agar (Blood Agar Base No. 2, Lab M, with egg yolk emulsion, Oxoid, $3 \% \mathrm{v} / \mathrm{v})$; Listeria selective medium prepared by a modification of the method of Kramer and Jones (1969) contained $(/ \mathrm{L})$ thallous acetate $60 \mathrm{mg}$, nalidixic acid $50 \mathrm{mg}$ and Tryptose Soy Agar (Difco) $40 \mathrm{~g}$, with $100 \mathrm{ml}$ of sterile horse serum type $\mathrm{V}$ (Wellcome) added after autoclaving; MacConkey Agar (Oxoid); liquid culture medium was proteose peptone broth (Proteose Peptone, Oxoid $15 \mathrm{~g}$, dextrose $2 \mathrm{~g}, \mathrm{NaCl} 8.5 \mathrm{~g}, \mathrm{Na}_{2} \mathrm{HPO}_{4} 2.5 \mathrm{~g}$, all $/ \mathrm{L}$ ).

\section{Chemical assays}

Protein was assayed by the method of Lowry et al. (1951) with bovine serum albumin (BSA) as the standard.

Carbohydrate was measured by the phenol-sulphuric acid method of Dubois et al. (1956) with glucose as the standard.

$R N A$ was assayed by the method of Albaum and Umbreit (1947) as modified by Ogur and Rosen (1950); and $D N A$ by the method of Burton (1956).

Free inorganic phosphate was assayed by the method of Ames (1966).

Inorganic phosphate was detected on paper chromatograms by spraying with ammonium molybdate $4 \% \mathrm{v} / \mathrm{v}$ and heating to $45^{\circ} \mathrm{C}$ for $10 \mathrm{~min}$ and then spraying with $\mathrm{FeSO}_{4} 3 \% \mathrm{w} / \mathrm{v}$ in $\mathrm{H}_{2} \mathrm{SO}_{4} 5 \% \mathrm{v} / \mathrm{v}$.

Glycerol was assayed with a test kit for triglycerides (Boehringer Manheim).

Fatty acids were assayed by adding $2 \mathrm{ml}$ of a copper reagent (1M acetic acid: $1 \mathrm{M}$ triethanolamine: cupric nitrate $6.45 \% \mathrm{w} / \mathrm{v}, 1: 9: 10 \mathrm{v}: \mathrm{v}: \mathrm{v})$ to stoppered test tubes containing $0.5 \mathrm{ml}$ of the test sample in $10 \mathrm{ml}$ of $\mathrm{CHCl}_{3}$. A standard solution contained $0.5 \mu \mathrm{mol}$ of stearic acid and a blank contained chloroform alone. The tubes were shaken for $2 \mathrm{~min}$, the upper blue layer was removed, the lower phase was filtered through Whatman No. 1 paper and then $0.2 \mathrm{ml}$ of sodium diethyldithiocarbamate $0.1 \%$ $\mathrm{w} / \mathrm{v}$ in butanol was added before the extinction at $440 \mathrm{~nm}$ $\left(E_{440}\right)$ was read against the blank.

\section{Biological and biochemical assays}

Haemolysin was estimated by serially diluting $0.5 \mathrm{ml}$ of a solution of the desalted exoprotein $10 \mathrm{mg} / \mathrm{ml}$ in

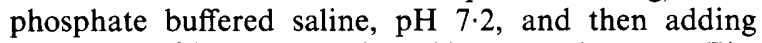
$0.5 \mathrm{ml}$ of a $3 \% \mathrm{v} / \mathrm{v}$ suspension of horse erythrocytes. The tubes were incubated at $37^{\circ} \mathrm{C}$ for $1 \mathrm{~h}$ in a water bath and the haemolytic titre was expressed as the last dilution that showed complete haemolysis (CHU). For the assay of thiol-activated haemolysin, $20 \mathrm{~mm}$ cysteine- $\mathrm{HCl}$ was included in the buffered saline ( $\mathrm{pH} 7 \cdot 2$ ).

Esterase/lipase activities were monitored by the hydrolysis of egg yolk, naphthyl esters and 4-nitrophenol esters. Egg yolk hydrolysis was determined by serial dilution of exoprotein $10 \mathrm{mg} / \mathrm{ml}$ in saline $0.85 \% \mathrm{w} / \mathrm{v}$ followed by the addition of $0.5 \mathrm{ml}$ of egg yolk emulsion (Oxoid) $3 \% \mathrm{v} / \mathrm{v}$ in saline. After incubation at $37^{\circ} \mathrm{C}$ for $12 \mathrm{~h}$, the last tube that showed opacity was taken as the end-point of the titration and the titre was expressed in lipolytic units (LU). The naphthyl-esters used were naphthyl-acetate, oleate, -stearate, -palmitate, -laurate and -caprate. The assay mixture consisted of $1 \mathrm{ml}$ of ester $10 \mathrm{mg} / \mathrm{ml}, 1 \mathrm{ml}$ of $0 \cdot 1 \mathrm{M}$ borate buffer, $\mathrm{pH} 7 \cdot 0$, and $1 \mathrm{ml}$ of exoprotein $5 \mathrm{mg} /$ $\mathrm{ml}$. Distilled water was used instead of the enzyme solution as a control. The mixtures were incubated at $37^{\circ} \mathrm{C}$ for $4 \mathrm{~h}$ in a shaking water bath; Fast Blue RR $1 \mathrm{mg} /$ $\mathrm{ml}$ in $0.1 \mathrm{M}$ borate buffer was added and the colour was noted after $15 \mathrm{~min}$. The 4-nitrophenyl esters used were 4nitrophenol-acetate, -laurate, -palmitate and -stearate. The acetate ester was used at a concentration of $1.67 \mathrm{~mm}$ but the other esters were used as $835 \mu \mathrm{M}$ solutions. The test solution contained $1.0 \mathrm{ml}$ of $30 \mathrm{mM} \mathrm{CaCl}_{2}, 1.0 \mathrm{ml}$ of exoprotein $10 \mathrm{mg} / \mathrm{ml}$ and $1.5 \mathrm{ml}$ of either $50 \mathrm{~mm}$ Tris$\mathrm{HCl}$ buffer, $\mathrm{pH} 7.0$, or $0.1 \mathrm{M}$ acetate buffer, $\mathrm{pH} 5.0$; the blank contained no exoprotein. The ester solution $(1.5 \mathrm{ml})$ was added to the test solution and $\mathrm{E}_{410}$ measurements were compared with the blank over a period of $15 \mathrm{~min}$ at $37^{\circ} \mathrm{C}$. Some spontaneous hydrolysis of the 4-nitrophenol substrate esters was observed under these reaction conditions.

Phospholipase was assayed by the hydrolysis of phosphatidylcholine (PC). The PC suspension was prepared by sonicating $\left(6 \times 30 \mathrm{~s}, 70 \mathrm{~W}, 0^{\circ} \mathrm{C}\right) \mathrm{PC} 100 \mathrm{mg}$, sodium deoxycholate $200 \mathrm{mg}, 0.75 \mathrm{ml}$ of $10 \mathrm{~mm}$ Tris- $\mathrm{HCl}$ buffer, $\mathrm{pH} 7 \cdot 0$, containing BSA (which had been dialysed overnight against $10 \mathrm{~mm}$ Tris- $\mathrm{HCl}$ buffer, $\mathrm{pH} \mathrm{7.0)} 1 \%$ $\mathrm{w} / \mathrm{v}$, and $0.25 \mathrm{ml}$ of $3 \mathrm{mM} \mathrm{CaCl}_{2}$ (Yamakawa and Ohsaka, 1977). The test solution contained $0.3 \mathrm{ml}$ of PC suspension plus $0.2 \mathrm{ml}$ of the enzyme solution (initially exoprotein $10 \mathrm{mg} / \mathrm{ml}$ ) or distilled water as a blank, and was incubated in stoppered centrifuge tubes at $37^{\circ} \mathrm{C}$ for $16 \mathrm{~h}$ in a shaking water bath. The reaction was stopped by the addition of $2.5 \mathrm{ml}$ of chloroform:methanol, $2: 1, \mathrm{v}: \mathrm{v}$, at $0^{\circ} \mathrm{C}$. The tubes were centrifuged for $15 \mathrm{~min}$ at $3000 \mathrm{~g}$ and $0.2 \mathrm{ml}$ of 
the methanol phase was transferred to stoppered centrifuge tubes which contained $0.5 \mathrm{ml}$ of $\mathrm{HClO}_{4} 60 \% \mathrm{v} / \mathrm{v}$. The tubes were heated at $160^{\circ} \mathrm{C}$ for $60 \mathrm{~min}$, and the volume was made up to $2.0 \mathrm{ml}$ with distilled water. Samples $(0.3 \mathrm{ml})$ were removed and assayed for inorganic phosphate. The hydrolysis of sphingomyelin and phosphatidyl ethanolamine was also monitored by this method.

Acid phosphatase was assayed by adding $0.2 \mathrm{ml}$ of exoprotein $10 \mathrm{mg} / \mathrm{ml}$ to $0.3 \mathrm{ml}$ of $45 \mathrm{mM}$ 4-nitrophenol phosphate in $0 \cdot 2 \mathrm{M}$ acetate buffer, $\mathrm{pH} 5 \cdot 0$. After incubation at $37^{\circ} \mathrm{C}$ for $30 \mathrm{~min}, 2.0 \mathrm{ml}$ of $50 \mathrm{~mm} \mathrm{NaOH}$ was added and the $E_{410}$ was read. Phosphatase activity was calculated by comparing the amount of 4-nitrophenol released with a standard curve of extinction versus 4nitrophenol concentration. The molar extinction coefficient for 4-nitrophenol hydrolysis at $410 \mathrm{~nm}$ was $5.57 \times$ $10^{5}$ under the above conditions.

The neutral phosphatase assay was similar to that for acid phosphatase except that $10 \mathrm{~mm}$ Tris- $\mathrm{HCl}$ buffer, $\mathrm{pH}$ $7 \cdot 0$, was used in place of the acetate buffer.

Alkaline phosphatase assays were performed with the same buffer at $\mathrm{pH} 10 \cdot 5$.

Phosphodiesterase assays used the phosphatase system but the substrate was bis-4-nitrophenol phosphate and the buffer was $10 \mathrm{~mm}$ Tris- $\mathrm{HCl}, \mathrm{pH} 6 \cdot 0$.

Catalase was assayed by adding $1 \mathrm{ml}$ of the exoprotein solution, $5 \mathrm{mg} / \mathrm{ml}$ in $0.1 \mathrm{M}$ Tris- $\mathrm{HCl}$, $\mathrm{pH} 7 \cdot 0$, to $2 \mathrm{ml}$ of $\mathrm{H}_{2} \mathrm{O}_{2} 5 \% \mathrm{v} / \mathrm{v}$ and examining for oxygen release.

Galactosidase was determined by incubating $1 \mathrm{ml}$ of the exoprotein $5 \mathrm{mg} / \mathrm{ml}$ with $2 \mathrm{ml}$ of $\alpha$ - or $\beta$ - nitrophenolgalactopyranoside $1 \mathrm{mg} / \mathrm{ml}$ in $0.1 \mathrm{M}$ borate buffer, $\mathrm{pH} 7 \cdot 2$, at $37^{\circ} \mathrm{C}$. After $30 \mathrm{~min}, 1 \mathrm{ml}$ of $0 \cdot 1 \mathrm{M}$ glycine- $\mathrm{NaCl}-\mathrm{NaOH}$ buffer, $\mathrm{pH} 9 \cdot 5$, was added, and the $\mathrm{E}_{410}$ was read. The control did not contain exoprotein.

NADase was assayed by the hydrolysis of NAD $(0.5 \mathrm{ml}$, $4 \mathrm{mg} / \mathrm{ml}$ ) by $0.5 \mathrm{ml}$ of exoprotein $5 \mathrm{mg} / \mathrm{ml} \mathrm{in} 1.0 \mathrm{ml}$ of $0 \cdot 1 \mathrm{M} \mathrm{KH}_{2} \mathrm{PO}_{4}$ according to the method of Kaplan et al. (1951); the $\mathrm{E}_{340}$ of the reaction mixture was compared to that of a blank without exoprotein.

RNAase was determined by adding $1.0 \mathrm{ml}$ of yeast RNA $10 \mathrm{mg} / \mathrm{ml}$ containing $25 \mathrm{mM} \mathrm{MgCl}_{2}$, to $5 \mathrm{mg}$ of exoprotein in $4.0 \mathrm{ml}$ of $0.1 \mathrm{M}$ barbitone buffer, $\mathrm{pH} 7.2$. The $E_{260}$ and $E_{300}$ values were monitored at $37^{\circ} \mathrm{C}$ for $1 \mathrm{~h}$ for RNA hydrolysis and compared with values for a sample without added exoprotein.

DNAase activity was determined by the method of Baman and Haque (1970) in which DNA is incorporated in agar; 4-mm wells were bored into the agar, and these were filled with $10,50,100$ and $200 \mathrm{mg} / \mathrm{ml}$ solutions of exoprotein. The plates were incubated at $37^{\circ} \mathrm{C}$ for 5 days and examined for clearing of the agar.

$\alpha$-Amylase was assayed by adding $1 \mathrm{ml}$ of exoprotein $10 \mathrm{mg} / \mathrm{ml}$ to $1 \mathrm{ml}$ of starch, $10 \mathrm{mg} / \mathrm{ml}$, buffered with $20 \mathrm{~mm}$ sodium glycerophosphate, and incubated at $37^{\circ} \mathrm{C}$ for $30 \mathrm{~min}$. Reducing activity was monitored against a blank which had no added exoprotein by adding $4 \mathrm{ml}$ of alkaline ferricyanide reagent (potassium ferricyanide $0.4 \mathrm{~g}+$ sodium carbonate $20 \mathrm{~g} / \mathrm{L}$ ).

API test strips (API Laboratory Products, Basingstoke) were used to screen for the following enzyme activities: acid phosphatase, alkaline phosphatase, esterase/lipase, peptidase/amidase, phosphoamidase, glycosidase, galactosidase, pyranosidase and glucoseaminidase. Each test well was inoculated with $50 \mu \mathrm{l}$ of exoprotein $20 \mathrm{mg} / \mathrm{ml}$ and incubated for $4 \mathrm{~h}$ at $37^{\circ} \mathrm{C}$; the enzyme activities were determined by comparison of the test wells with the colour chart supplied.

\section{Mouse passage}

Two strains of L. monocytogenes, Boldy (serotype 4) and NCTC 7973 (serotype 1), were passaged through mice in an attempt to increase haemolysin and phospholipase production; strain NCTC 7973 was a weak producer of phospholipase and haemolysin. Two groups of three adult mice were infected intraperitoneally with $0.2 \mathrm{ml}$ of an exponentially growing culture of one of the L. monocytogenes strains. The mice were examined daily, and a general decrease in their activity was observed. One mouse from each group died on the fourth day and the others were then killed. Samples from the spleen, faeces, heartblood, and peritoneal exudate were taken for culture. Haemolytic colonies of Listeria were checked for purity by subculture on Listeria selective media and MacConkey agar, and by Gram's stain, and tests for motility, fermentation of sugars, and serotyping. Passage through mice was repeated three times. All isolates were examined for haemolysin and phospholipase production on blood agar and egg yolk agar respectively.

\section{Determination of the nature of the phospholipase activity}

Highly purified PC $(250 \mathrm{mg})$ was re-suspended in $2.0 \mathrm{ml}$ of double-distilled water by sonication for a total of $3 \mathrm{~min}$ at $0^{\circ} \mathrm{C}$. Part $(10 \mu \mathrm{l})$ of the suspension was removed and stored at $-20^{\circ} \mathrm{C}$ for use later as a control. The remainder was divided into two portions and added to stoppered centrifuge tubes containing(i) $\mathrm{CaCl}_{2} 3 \mu \mathrm{mol}$, sodium deoxycholate $150 \mu \mathrm{mol}$ and BSA (which had been dialysed overnight against $50 \mathrm{~mm}$ Tris- $\mathrm{HCl}$ buffer, $\mathrm{pH}$ $7 \cdot 2,0.1 \% \mathrm{w} / \mathrm{v}$ ) in $0.5 \mathrm{ml}$ of $50 \mathrm{~mm}$ Tris- $\mathrm{HCl}$ buffer, $\mathrm{pH}$ $7 \cdot 2$, or (ii) the same ingredients plus strain Type 5 protein $20 \mathrm{mg}$. Both tubes were incubated, with shaking, at $37^{\circ} \mathrm{C}$ for $4 \mathrm{~h}$. The reaction was stopped by the addition of $2.5 \mathrm{ml}$ of $\mathrm{CHCl}_{3}: \mathrm{MeOH}\left(2: 1\right.$, v:v) at $0^{\circ} \mathrm{C}$. The tubes were centrifuged at $2000 \mathrm{~g}$ for $15 \mathrm{~min}$ and the resulting two phases were separated.

(a) Treatment of the methanol phase. The free inorganic phosphate $\left(\mathrm{P}_{\mathrm{i}}\right)$ and the total $\mathbf{P}_{\mathrm{i}}$ were assayed by adding $0 \cdot 2-\mathrm{ml} \mathrm{samples}$ from each methanol phase to two $0.5-\mathrm{ml}$ volumes of $\mathrm{HClO}_{4}$. A sample from each extract was heated at $165^{\circ} \mathrm{C}$ for $1 \mathrm{~h}$ for a total $\mathrm{P}_{\mathrm{i}}$ estimation, whilst the second, which contained free $P_{i}$, was held at $0^{\circ} \mathrm{C}$ for the same period. Both samples were then assayed for inorganic phosphate. Samples $(25 \mu \mathrm{l})$ of each methanol phase were examined for phosphate esters by chromatography on Whatman No. 1 filter-paper developed with butanol:acetic acid: water $(5: 2: 3, \mathrm{v}: \mathrm{v}: \mathrm{v})$ by the method 
of Schneider et al. (1966). The phosphate esters were detected by spraying with ammonium molybdate reagent as described above (Chemical assays).

(b) Treatment of the chloroform phase. The chloroform phases were dried under a stream of $\mathrm{N}_{2}$ gas, and redissolved in $1.0 \mathrm{ml}$ of chloroform. Duplicate $0.2-\mathrm{ml}$ samples were examined by thin layer chromatography on a $0.5-\mathrm{mm}$ thick silica gel $\mathrm{G}$ plate developed with diisopropyl ether:acetic acid $(24: 1, \mathrm{v}: \mathrm{v})$. Lipids were detected by spraying the plates with 2,7 dichlorofluorescein $0.1 \% \mathrm{w} / \mathrm{v}$ in ethanol and examining the plate under UV $(254 \mathrm{~nm})$ illumination. The separated reaction products were extracted with ether which was later evaporated under $\mathrm{N}_{2}$ gas. The residues were taken up in $2.0 \mathrm{ml}$ of ether:ethanol solution $(1: 1, \mathrm{v}: \mathrm{v})$. Each solution was mixed with $3.0 \mathrm{ml}$ of $0.1 \mathrm{M} \mathrm{NaOH}$, and heated at $65^{\circ} \mathrm{C}$ for $1 \mathrm{~h}$ in stoppered tubes. When the tubes had cooled to $20^{\circ} \mathrm{C}$, the volumes were re-adjusted to the levels before hydrolysis, and each solution was assayed for glycerol and fatty-acid content.

\section{Results and Discussion}

\section{Exoprotein production on solid media}

Only 62 strains exhibited haemolytic activity alone, 20 , including the two strains of $L$. ivanovii, were both haemolytic and lipolytic and 40 strains showed neither haemolytic nor lipolytic activity. Only 32 of the 122 strains were examined for esterase/lipase activity but all of these gave positive results. There was no correlation between the enzyme activities observed and the serotype of the organisms tested. As all of these strains had been reported to produce haemolysis when they were first isolated, and we know that at least someNewcastle, Cobb, Boldy, Palmar and Pontefract (Leighton et al., 1975), NCTC 7973, NCTC 5105 and NCTC 5214 (Khan et al., 1972)-also produced a phospholipase, it appeared that many of the nonproducing cultures had lost their ability to produce a haemolysin or a phospholipase, possibly by becoming adapted to laboratory media. However, the complete loss of the ability to secrete a phospholipase seemed unlikely because we were able, later, to induce phospholipase production in apparently non-phospholytic, but haemolysin-producing, strains by incubating them for at least 10 days at $4^{\circ} \mathrm{C}$ on Kramer-Jones (1969) agar containing PC $3 \% \mathrm{w} / \mathrm{v}$. Passage of some of these strains through mice (see Methods) failed to induce the production of haemolysin or phospholipase, although some of the infections were fatal. Thus, it is conceivable that an apparently non-haemolytic strain of $L$. monocytogenes could be isolated from an infection. Coupled with the fact that haemolysin production is an important criterion for the identification of $L$. monocytogenes and L. ivanovii, it is possible that the clinical identification of this organism could be delayed with potentially fatal consequences.

The confinement of phospholipase activity to haemolysin-producing strains, coupled with the concomitant decrease in the secretion of phospholipase and haemolysin, suggested a relationship. between haemolysin production and the presence of a phospholipase.

\section{Production of haemolytic and lipolytic activities in liquid media}

Two strains (L. ivanovii Type 5 and L. monocytogenes Boldy) that produced the greatest amounts of haemolytic and lipolytic activities on solid media were chosen as models for exoprotein production. Haemolysin was detected in static but not in shake cultures of the L. ivanovii strain at $37^{\circ} \mathrm{C}$ (figs. 1 a and b). Lipolytic activity was detected in both cultures, but the level was slightly lower in shake than in static culture. Similar results were found with $L$. monocytogenes Boldy but the lag period before production of these exoproteins was longer than for L. ivanovii Type 5. Similarities with previous reports on the production of the haemolysins were noted. The production of haemolysin by L. ivanovii Type 5 at $37^{\circ} \mathrm{C}$ without shaking was similar to that reported by Njoku-Obi et al. (1963) for strains NCTC 7973, 7648 and 452 , and that by strain Boldy was like the results reported for strains 9-125 (Girard et al., 1963) and $5214 \mathrm{M}$ (Khan et al., 1972). The lag differences in the growth curves may be explained either by differences in the viability of the inocula in the growth medium used or by differences in the ability of the strains to produce exoprotein. As only a few strains were examined, we cannot state that the apparent strain differences are significant, but these findings do show that exoprotein production depends on the growth conditions.

\section{Enzyme activities associated with culture filtrates of strains Type 5 and Boldy}

Examination of the gel filtration elution profiles from other reports (Jenkins and Watson, 1971; Siddique et al., 1974) showed a large amount of exoprotein that was not associated with the haemolytic and lipolytic activities. We grew strains Type 5 and Boldy, harvested their exoproteincontaining culture filtrates and assayed these for potential hydrolytic enzyme activities. Ammonium sulphate $(0-65 \% \mathrm{v} / \mathrm{v})$ precipitates from the cell-free 


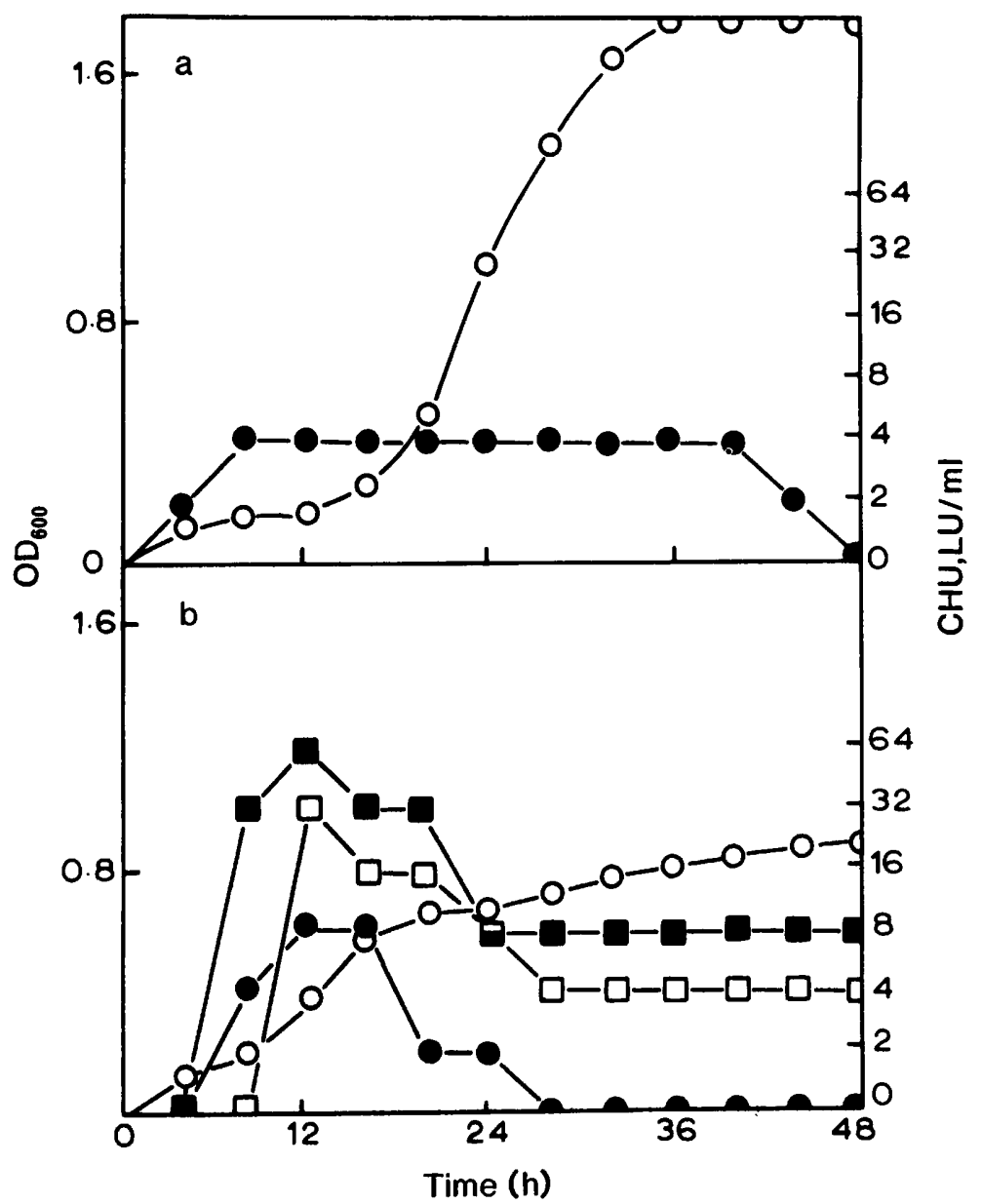

Fig. 1. Time course of exoprotein production by L. ivanovii Type 5 in proteose peptone broth at $37^{\circ} \mathrm{C}$, (a) with shaking, (b) without shaking. $\bigcirc$ Cell density $\mathrm{OD}_{600} ;$ lipolytic activity (LU); $\square$ thiol-independent haemolytic activity (CHU); $\square$ thiol-activated haemolytic activity (CHU).

media of 16-24-h cultures of strains Type 5 and Boldy were desalted by passage through Sephadex G-25 before being assayed for the enzyme activities shown in table I. Later studies with purified enzymes (Barclay et al., 1989) showed that the phosphatase activity was due to the combined activities of an acid and a neutral phosphatase which had pH optima of 5.0 $(5 \cdot 7 \mathrm{nmol} 4$-nitrophenol phosphate hydrolysed $/ \mathrm{mg}$ of protein $/ \mathrm{min}$ ) and 7.0 $(4.3 \mathrm{nmol} / \mathrm{mg} / \mathrm{min})$ respectively. Maximum phosphodiesterase activity was at $\mathrm{pH} 6(1.32 \mathrm{nmol}$ of bis-4-nitrophenolphosphate hydrolysed/mg of protein/min) but the true phosphodiesterase activity may have been less than half of this value because the 4-nitrophenol phosphate released by the phosphodiesterase in the assay could have been further hydrolysed by the action of the phosphatases present in the exoprotein mixture.
Therefore, we have shown the presence of previously unreported hydrolytic enzymes in the culture filtrates of $L$. monocytogenes and $L$. ivanovii (table I). As these enzymes could be expected to contribute to the virulence of $L$. monocytogenes and L. ivanovii, they may explain some of the physiologically detrimental properties such as cardiac toxicity that were previously attributed to the haemolysin (Sword and Kingdon, 1971).

\section{Nature of the phospholipase activity}

The phospholipase activity, as detected by the release of inorganic phosphate, could have represented either the production of a phospholipase C, or the combined activities of a phospholipase D plus phosphomonoesterase. Samples $(125 \mathrm{mg})$ of highly purified PC were incubated for $4 \mathrm{~h}$ at $37^{\circ} \mathrm{C}$ 
Table I. Activities associated with the exoproteins of strains L. ivanovii Type 5 and L. monocytogenes Boldy at $37^{\circ} \mathrm{C}$

\begin{tabular}{|c|c|c|c|c|c|}
\hline \multirow[b]{2}{*}{ Activity* } & \multicolumn{3}{|c|}{ Assay conditions } & \multicolumn{2}{|c|}{$\mathrm{CHU} \dagger$} \\
\hline & $\mathrm{pH}$ & Substrate & $\begin{array}{l}\text { Incubation } \\
\text { time (h) }\end{array}$ & Type 5 & Boldy \\
\hline Thiol-independent haemolysin & $7 \cdot 2$ & Horse erythrocytes & 1 & 64 & 4 \\
\hline Thiol-activated haemolysin & $7 \cdot 2$ & Horse erythrocytes & 1 & \multicolumn{2}{|c|}{$\begin{array}{c}\text { Rates (nmol/mg of protein } / \\
\min \text { ) }\end{array}$} \\
\hline Phosphatase & $\begin{array}{r}5 \cdot 0 \\
7 \cdot 0 \\
10 \cdot 5\end{array}$ & 4-Nitrophenol phosphate & $\begin{array}{l}0 \cdot 5 \\
0 \cdot 5 \\
0 \cdot 5\end{array}$ & $\begin{array}{l}5 \cdot 7 \\
3 \cdot 8 \\
0 \cdot 24\end{array}$ & $\begin{array}{l}3 \cdot 65 \\
2 \cdot 2 \\
0 \cdot 17\end{array}$ \\
\hline Phosphodiesterase & $6 \cdot 0$ & bis-4-Nitrophenol phosphate & 0.5 & $1 \cdot 32$ & 0.73 \\
\hline Phospholipase & $7 \cdot 0$ & $\begin{array}{l}\text { Phosphatidylcholine } \\
\text { Phosphatidylethanolamine } \\
\text { Sphingomyelin }\end{array}$ & $\begin{array}{l}16 \\
16 \\
16\end{array}$ & $\begin{array}{l}0 \cdot 8 \\
0 \cdot 52 \\
0 \cdot 36\end{array}$ & $\begin{array}{l}0 \\
0 \\
0\end{array}$ \\
\hline Esterase & $7 \cdot 0$ & 4-Nitrophenol acetate & $0 \cdot 25$ & $0 \cdot 70$ & 0.78 \\
\hline Lipase & $7 \cdot 0$ & Synthetic triglycerides & 4 & \multicolumn{2}{|c|}{ Not measured } \\
\hline Phosphoamidase & $5 \cdot 4$ & Naphthol-AS-B1-phosphodiamide & 4 & \multicolumn{2}{|c|}{ Not measured } \\
\hline NADase & $7 \cdot 2$ & NAD & 1 & 0.035 & 0 \\
\hline Catalase & $7 \cdot 0$ & $\mathrm{H}_{2} \mathrm{O}_{2}$ & - & \multicolumn{2}{|c|}{ Not measured } \\
\hline
\end{tabular}

* The following enzyme activities were not detected : RNAase, DNAase, fucosidase, galactosidase, glucose aminidase, glucuronidase, glucosidase, protease and $\alpha$-amylase.

$\nmid$ Complete haemolytic units.

in the presence or absence of $20 \mathrm{mg}$ of strain Type 5 exoprotein and then extracted with chloroform:methanol (2:1) (see Materials and methods). The chloroform and methanol soluble compounds were analysed for the potential hydrolytic products of PC using TLC (table II) and paper chromatography. The methanol extract gave a single spot on paper chromatography which stained as a phosphate ester (blue) with ammonium molybdate reagent, and coincided with the phosphoryl choline marker. Only $3 \mu \mathrm{mol}$ of free phosphate were present in the methanol-soluble phase after the enzyme hydrolysis. However, when the methanol-soluble products were hydrolysed further, under acidic conditions at $160^{\circ} \mathrm{C}, 51 \mu \mathrm{mol}$ of free phosphate were detected. Also, a small amount $(3 \mu \mathrm{mol})$ of phosphoryl choline was hydrolysed to choline plus free inorganic phosphate by the action of a phosphatase. We considered the amount of this latter hydrolysis to be small, considering the presence of the phosphatases. Possibly the liposomal nature of the ultrasonically-treated PC prevented the phosphatases from gaining access to the phosphoryl choline.

Taken together, the results (above and table II) were consistent with the PC $(50-60 \mu \mathrm{mol})$ being hydrolysed by a phospholipase $\mathrm{C}$ to form equimolar amounts of phosphoryl choline $(51 \mu \mathrm{mol})$ and diglyceride $(50.7-58.6 \mu \mathrm{mol})$, and a proportion of the diglyceride $(12 \cdot 3-15 \cdot 6 \mu \mathrm{mol})$ then being hydrolysed to monoglycerides and fatty acids $(15 \cdot 7 \mu \mathrm{mol})$ by the action of a lipase.

Table II. Thin layer chromatography of phosphatidyl choline hydrolysis products

\begin{tabular}{lccc}
\hline \multicolumn{1}{c}{ Product } & $\mathrm{R}_{\mathrm{f}}$ & $\begin{array}{c}\text { Glycerol } \\
\text { content } \\
(\mu \mathrm{mol})\end{array}$ & $\begin{array}{c}\text { Fatty acid } \\
\text { content } \\
(\mu \mathrm{mol})\end{array}$ \\
\hline Diglyceride & 0.54 & $35 \cdot 1$ & $92 \cdot 4$ \\
Monoglyceride & $0 \cdot 21$ & $15 \cdot 6$ & $12 \cdot 3$ \\
Fatty acid & 0.69 & 0 & $15 \cdot 7$ \\
Sodium deoxycholate & 0.07 & 0 & 0 \\
Total estimated glyceride & - & $50 \cdot 7$ & 58.6 \\
\hline
\end{tabular}

Phosphatidyl choline $(125 \mathrm{mg}$ ) was hydrolysed by strain Type 5 exoprotein $(20 \mathrm{mg})$ for $4 \mathrm{~h}$ at $37^{\circ} \mathrm{C}$. The chloroform-soluble hydrolysates were separated by TLC on silica gel $G$ and developed with di-isopropyl ether: acetic acid $(24: 1, \mathrm{v}: \mathrm{v})$. The separated products were assayed for their glycerol and fatty acid contents after hydrolysis with hog pancreatic lipase. No hydrolytic products were detected in controls without exoprotein. The values are averages of three determinations. 


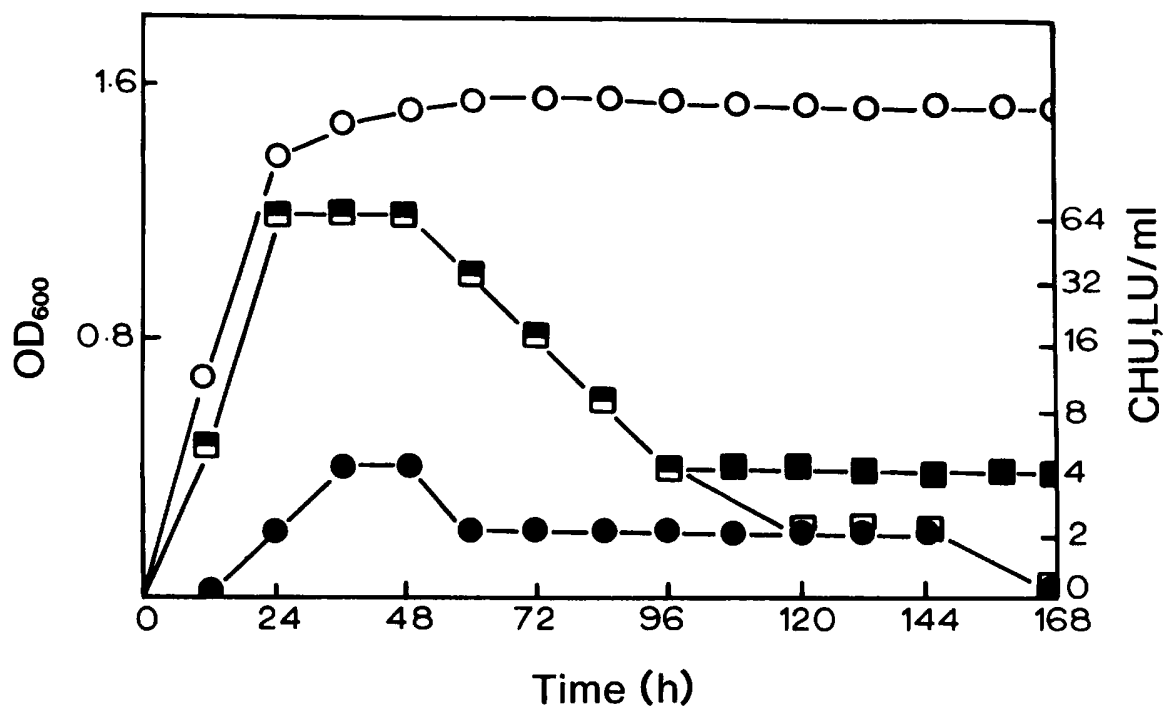

Fig. 2. Time course of exoprotein production by L. monocytogenes Boldy in proteose peptone bropth at $37^{\circ} \mathrm{C}$ without shaking. $\bigcirc \mathrm{Cell}$ density $\mathrm{OD}_{600}$; lipolytic activity (LU); $\square$ thiol-independent haemolytic activity (CHU); $\square$ thiol-activated haemolytic activity (CHU).

\section{Esterase/lipase activities of precipitate strain Type 5}

Substrate specificities of strain Type 5 exoprotein were estimated with triglycerides, naphthyl esters and 4-nitrophenol esters. The results suggested that short chain $\left(\mathrm{C}_{2}-\mathrm{C}_{4}\right)$ fatty-acid esters were preferentially hydrolysed (table III). Examination of the production of esterase/lipase and phospholipase activities showed that several factors contributed to the confusion over the nature of the lipolytic activity. These included the use of different strains and growth conditions by different laboratories, the adaptation of the organisms to laboratory culture media and the small amounts of enzymes produced. The apparent dependence of phospholipase production on the secretion of haemolysin has probably added to this confusion, but is also interesting because most of the exoproteins that we have described could act synergically. Thus, it is possible to envisage that the host cell membrane is disrupted by the haemolysin and the phospholipid released is then hydrolysed by the combined activities of the

Table III. Lipase and esterase activities of strain Type 5 exoprotein

\begin{tabular}{|c|c|c|c|c|c|c|c|}
\hline \multicolumn{2}{|c|}{ Turbidity } & \multicolumn{4}{|c|}{ Coloured chromophore } & \multicolumn{2}{|c|}{ Spectrophotometric assay } \\
\hline Substrate & Score & Substrate & $\begin{array}{l}\text { Colour of } \\
\text { positive } \\
\text { reaction }\end{array}$ & Score & $\begin{array}{l}\text { Number of } \\
\text { carbon atoms } \\
\text { in fatty } \\
\text { acid chain }\end{array}$ & Substrate & $\begin{array}{c}\text { Rate } \\
(\mathrm{nmol} / \mathrm{mg} / \mathrm{min})\end{array}$ \\
\hline Tween 80 & + & N-Acetate & Brown & $+t+$ & 2 & 4-NP-Acetate & 0.7 \\
\hline Triacetin & +++ & $\begin{array}{l}\text { N-Butyrate } \\
\text { N-Caprate }\end{array}$ & $\begin{array}{l}\text { Brown } \\
\text { Brown }\end{array}$ & $\begin{array}{c}++ \\
++\end{array}$ & $\begin{array}{r}4 \\
10\end{array}$ & 4-NP-Laurate & $0 \cdot 2$ \\
\hline Tripalmitin & - & N-Laurate & Brown & ++ & 12 & 4-NP-Palmitate & $0 \cdot 17$ \\
\hline Triolein & ++ & $\begin{array}{l}\text { N-Myristate } \\
\text { N-Palmitate } \\
\text { N-Stearate } \\
\text { N-Oleate }\end{array}$ & $\begin{array}{c}\text { Brown } \\
\text { Brown } \\
\text { Brown } \\
\text { Red }\end{array}$ & $\begin{array}{c}+ \\
++ \\
- \\
++\end{array}$ & $\begin{array}{l}14 \\
16 \\
18 \\
18\end{array}$ & 4-NP-Stearate & 0 \\
\hline
\end{tabular}

$\dagger$ Scored on a,,++++++ scale of turbidity. $\mathrm{N}=$ naphthyl; $\mathrm{NP}=$ nitrophenol. 
phospholipase, esterase/lipase and phosphatases. Phospholipase production depended on, but was not completely determined by, haemolysin production as some strains produced haemolysin but no phospholipase, and also phospholipase production

\section{REFERENCES}

Albaum H G, Umbriet W W 1947 Differentiation between ribose-3-phosphate and ribose-5-phosphate by means of the orcinol-pentose reaction. Journal of Biological Chemistry 167: 369-376.

Ames B N 1966 Assay of inorganic phosphate, total phosphate and phosphatase. In: Neufield E F, Ginsburg V (eds) Methods in enzymology vol. 8. Academic Press, New York, pp 115-118.

Baman S I, Haque R 1970 Production of multivalent extracellular filtrates of Staphylococcus aureus. Canadian Journal of Microbiology 16: 1255-1261.

Barclay R, Threlfall D R, Leighton I 1989 Separation and properties of the haemolysins and extracellular enzymes of Listeria monocytogenes. Journal of Medical Microbiology 30: 119-127.

Burton K 1956 A study of the conditions and mechanism of the diphenylamine reaction for the colorimetric estimation of deoxyribonucleic acid. Biochemical Journal 62: 315-323.

Dubois M, Gilles K A, Hamilton J K, Rebers P A, Smith F 1956 Colorimetric method for determination of sugars and related substances. Analytical Chemistry 28: 350-356.

Girard K F, Sbarra A J, Bardawil W A 1963 Serology of Listeria monocytogenes. 1. Characteristics of the soluble hemolysin. Journal of Bacteriology 85 : 349-355.

Harvey P C, Faber J E 1941 Some biochemical reactions of the Listerella group (Abstract). Journal of Bacteriology 41 : $45-$ 46.

Jenkins E M, Watson B B 1971 Extracellular antigens from Listeria monocytogenes. 1. Purification and resolution of hemolytic and lipolytic antigens from culture filtrates of Listeria monocytogenes. Infection and Immunity 3: 589-594.

Kaplan N O, Colowick S P, Nason A 1951 Neurospora diphosphopyridine nucleotidase. Journal of Biological Chemistry 191 : 473-483.

Khan M A, Seaman A, Woodbine M 1972 Listeria monocytogenes-haemolysin: lecithinase. Acta Microbiologa Academiae Scientiarum Hungaricae 19: 341-352.

Kramer P A, Jones D 1969 Media selective for Listeria monocytogenes. Journal of Applied Bacteriology 32: 381-394.

Leighton I, Threlfall D R, Oakley C 1975 Phospholipase C could be stimulated in some strains by maintenance of the organisms at $4^{\circ} \mathrm{C}$.

R. B. thanks the SRC and Humberside Area Health Authorities for the award of a CASE studentship.

activity in culture filtrates of Listeria monocytogenes Boldy. In Woodbine M (ed) Problems of listeriosis. Proceedings of the VI International Symposium, Leicester University Press, Leicester, pp 239-241.

Lowry O H, Roseborough N J, Farr A L, Randall R J 1951 Protein measurement with the folin phenol reagent. Journal of Biological Chemistry 193: 265-275.

Njoku-Obi A N, Jenkins E M, Njoku-Obi J C, Adams J, Covington V 1963 Production and nature of Listeria monocytogenes hemolysins. Journal of Bacteriology 86: 1-8.

Ogur M, Rosen G 1950 The nucleic acids of plant tissues. I. The extraction and estimation of desoxypentose nucleic acid and pentose nucleic acid. Archives of Biochemistry 25: 262276.

Patocka F, Mara M 1973 Contribution to knowledge of factors participating in virulence of Listeria monocytogenes. 1. Isolation and properties of the biologically active complex E. Journal of Hygiene, Epidemiology, Microbiology and Immunology 17: 457-468.

Schneider W C, Fiscus W G, Lawler J B 1966 Enzymic preparation of labelled phosphoryl choline, phosphoryl ethanolamine, cytidine diphosphate choline, deoxycitidine diphosphate choline, cytidine diphosphate ethanolamine, and deoxcytidine diphosphate ethanolamine. Analytical Biochemistry 14: 121-134.

Seeliger H P R 1961 Listeriosis, Hafner Publishing Co., New York.

Siddique I H, Lin I-F, Chung R A 1974 Purification and characterisation of haemolysin produced by Listeria monocytogenes. American Journal of Veterinary Research 35: 289 296.

Stanley N F 1949 Studies on Listeria monocytogenes. 1. Isolation of a monocytosis producing agent (MPA). Australian Journal of Experimental Biology and Medical Science 27: 123-131.

Sword C P, Kingdon G C 1971 Listeria monocytogenes toxin. In Kadis S et al. (eds) Microbial toxins-bacterial protein toxins. Academic Press, New York and London, pp 357377.

Yamakawa Y, Ohsaka A 1977 Purification and some properties of phospholipase $C$ ( $\alpha$-Toxin) of Clostridium perfringens. Journal of Biochemistry 81 : 115-126. 